\title{
Sweet Sorghum Genotypes Testing in the High Latitude Rainfed Steppes of the Northern Kazakhstan (for Feed and Biofuel)
}

\author{
Rauan Zhapayev $^{1}$, Kulyash Iskandarova ${ }^{2}$, Kristina Toderich ${ }^{3}$, Irina Paramonova ${ }^{4}$, Abdullah Al-Dakheel ${ }^{3}$, Shoaib \\ Ismail $^{3}$, Srinivasa Rao Pinnamaneni ${ }^{5}$, Aiman Omarova ${ }^{6}$, Nina Nekrasova ${ }^{4}$, Darhan Balpanov ${ }^{4}$, Oleg Ten ${ }^{4}$, Erlan \\ Ramanculov $^{2}$, Yuriy Zelenskiy ${ }^{1}$, Aigul Akhmetova ${ }^{1}$ and Muratbek Karabayev ${ }^{1}$ \\ 1. International Maize and Wheat Improvement Center, Mexico D. F. 06600, Mexico \\ 2. National Center for Biotechnology, Astana 010000, Kazakhstan \\ 3. International Center for Biosaline Agriculture, Dubai 14660, United Arab Emirates \\ 4. Scientific and Analytical Center “Biomedpreparat”, Stepnogorsk 021500, Kazakhstan \\ 5. International Crops Research Institute for the Semi-arid Tropics, Patancheru 502324, Andhra Pradesh, India \\ 6. Kazakh Research Institute of Farming and Crop Production, Almaty 040909, Kazakhstan
}

\begin{abstract}
Twenty-eight sweet sorghum (Sorghum bicolor (L.) Moench) genotypes of the different ecological and geographic origins: Kazakhstan, Russia, India, Uzbekistan, and China were tested in the high latitude rainfed conditions of northern Kazakhstan. The genotypes demonstrated high biomass production (up to $100 \mathrm{t} \cdot \mathrm{ha}^{-1}$ and more). The genotypes ripening to full reproductive seeds were selected for seed production and introduction in the northern Kazakhstan. Lactic acid bacteria Lactobacillus plantarum S-1, Streptococcus thermophilus F-1 and Lactococcus lactis F-4 essentially enhance the fermentation process, suppressing undesirable microbiological processes, reducing the loss of nutrient compounds, accelerating in 2 times maturation ensilage process and providing higher quality of the feed product.
\end{abstract}

Key words: Sweet sorghum, ecological testing, high latitude, biomass, ensiling, climate change mitigation.

\section{Introduction}

The territory of Kazakhstan is of 2.7 million $\mathrm{km}^{2}$, which is $70 \%$ of the land of Central Asia. Kazakhstan ranks 9th place all over the world in the area extent. Around 20.0 Mha of Kazakhstan's land area is used for crop production, mainly for cereals. The most part of the cropping area is located in the unfavorable zones. The acutely continental climate of Kazakhstan aggravated by its appreciable changes last decades, frequent droughts and diseases, wind and water erosion, and soil fertility decrease have became the most important tasks and challenges for Kazakhstani food security and export potential improvement $[1,2]$.

Corresponding author: Rauan Zhapayev, Ph.D., research field: agronomy. E-mail: r.zhapayev@cgiar.org.
Livestock sector and biofuel production declared as priority directions of the Kazakhstani economics compete for the vegetable substrate and the very need in actively renewable sources of biomass [3]. Introduction of high yielding and drought-resistant crops capable to grow in wide range of soil-climatic conditions, active mobilization of world plant genetic resources, conservation agriculture and biotechnologies for their production and processing can be one of the most effective ways and solutions of the problems $[4,5]$. The research and extension activities based on sorghum, one of the most drought resistant, high-yielding and low-input crops in the world, can enable in short time to create sustainable basis for intensive livestock and biofuel productions-important components of the national food and energy security. 

Northern Kazakhstan (for Feed and Biofuel)

Geographical location and climatic conditions of the northern Kazakhstan make special requirements to genetic and physiological characteristics of sorghum introduced. First of all, high latitude sorghum genotypes have to combine relatively high biomass production with maturity to reproductive seeds generation [6]. Processing of the green biomass is also important for feed improvement in the region. One of the effective methods of the forage preservation is the ensiling of the biomass based on lactic acid bacteria converting water-soluble carbohydrates into organic acids under anaerobic conditions [7].

The purpose of the present study was to investigate sorghum yield potential in high latitude conditions of the northern Kazakhstan, to select the best adapted genotypes and to develop effective methods for biomass processing.

\section{Material and Methods}

\subsection{Genotypes and Testing Details}

Twenty-eight sweet sorghum genotypes originated from different countries (Kazakhstan, Uzbekistan, Russia, China and India) and eco-geographic zones (Central and South Asia, East Europe and West Siberia) were the main objects of the research. Planting date is May 30. The trials were carried out in three replications. The experimental plots were located at Shortandy village, Akmola province, Kazakhstan ( $\left.51^{\circ} 65^{\prime} 06^{\prime \prime} \mathrm{N} ; 71^{\circ} 03^{\prime} 75^{\prime \prime} \mathrm{E}\right)$. Size of each plot was equal to $5 \mathrm{~m}^{2}$. The biomass yields were accounted at the end of the vegetation period (September 1-10). The "Origin Pro 7.5" was used for statistical analysis of experimental data.

\subsection{Soil and Climate Conditions in the Region}

The climatic conditions of Akmola region, which is located in the northern Kazakhstan, are characterized as sharp continental and arid. The sum of positive temperatures during the warm period is about 2,600 ${ }^{\circ} \mathrm{C}$, and the sum of temperatures is above $+10{ }^{\circ} \mathrm{C}\left(2,200-2,500{ }^{\circ} \mathrm{C}\right)$. The average length of frost-free period is $110-115$ days. The vegetation period is short. About $50 \%$ of the years are dry. Annual precipitations in Akmola region are about 300 $\mathrm{mm}$, evaporation level $-600-800 \mathrm{~mm}$.

The type of the soil in the area of research is southern carbonate chernozem. Humus content is in the range of $3.4 \%$ to $4.1 \%$. Potential soil fertility is relatively high, but under drought conditions, it is not realized effectively.

\subsection{Weather Conditions during the Vegetation Periods of the Trials}

Weather data for the vegetation period of the trials years (2011-2013) in Akmola region are presented in Table 1. In general, the precipitations and air temperatures were typical for the rainfed steppes of the northern Kazakhstan.

\subsection{Bacteria Strains and Ensiling Conditions}

Lactic acid bacteria Lactobacillus acidophilus F-3, Lactobacillus bulgaricus F-2, Lactococcus lactis F-4, Lactobacillus plantarum S-1, Streptococcus thermophilus F-1, and Streptococcus cremoris S-3 were taken from the Collection of Industrial Microorganisms of the Stepnogorsk Branch of the National Center for Biotechnology.

The effect of lactic acid bacteria on the sorghum ensiling was studied under laboratory conditions. The green mass stalks and leaves of sweet sorghum plant at the stage of wax ripeness were used.

The experiments were conducted at the temperature

Table 1 Precipitations and air temperatures for the vegetation period (May-August) in Akmola region in 2011 and 2013.

\begin{tabular}{|c|c|c|c|c|c|c|}
\hline \multirow{2}{*}{ Year } & \multicolumn{3}{|c|}{ Precipitation (mm) } & \multicolumn{3}{|c|}{ Air temperature $\left({ }^{\circ} \mathrm{C}\right)$} \\
\hline & May-August & Long-term mean & \pm Long-term mean & May-August & Long-term mean & \pm Long-term mean \\
\hline 2011 & 197.9 & 166.1 & +31.8 & 17.1 & 17.3 & -0.2 \\
\hline 2013 & 169.6 & 166.1 & +3.5 & 17.3 & 17.3 & 0.0 \\
\hline
\end{tabular}



Northern Kazakhstan (for Feed and Biofuel)

of $20 \pm 2{ }^{\circ} \mathrm{C}$ and humidity of $65 \%-75 \%$. The lactic acid bacteria inoculums were added at the initial content of $10^{7}$ cells in $1 \mathrm{mg}$ of the fermented biomass. Silages with no additives served as control. Indicators of silage quality (color, smell, $\mathrm{pH}$, mass fraction of lactic, acetic and butyric acids) were determined in 15 days and 30 days of ensiling in accordance with the official standard [8].

\section{Results and Discussion}

During the short vegetation period, unfavorable climatic conditions of the northern Kazakhstan require mobilization of wide range of plant genetic resources for testing, adaptation and introduction of the best sorghum genotypes. Assessments of different sorghum genotypes on their biological and economically valuable traits: adaptability, productivity, resistance to biotic and abiotic stresses, reproductive seed production, as well as effective processing and storage of the plant material are the top priority tasks for the region and country.

\subsection{Assessment of Sweet Sorghum Varieties and Lines in the Northern Kazakhstan}

The weather conditions and vegetation period of 2011 , the 1 st year of the experiments, in the area of the field trials were typical for the region. The period of May 20-31 was characterized by abundant rains which contributed to the accumulation of moisture in the soil by the time of sowing. Sorghum genotypes were seeded in May 30-the optimal time for the crops planting in the region. Sufficient rainfall in June and July contributed to the preservation of moisture in the soil by early August. The period of August 1-10 was characterized by the absence of precipitation on the background of decreased (by $1.8{ }^{\circ} \mathrm{C}$ ) air temperature. There were only $16.1 \mathrm{~mm}$ of precipitations in August, which was 2 times less in comparison with the average annual rate. However, good moisture pre-accumulation and low temperatures allowed the plants to pass through the August drought.
The total amount of precipitation was $197.9 \mathrm{~mm}$ at the average rate of $166.1 \mathrm{~mm}$. The level of green biomass yield of sweet sorghum varieties studied was relatively high.

Phenological observations of sweet sorghum varieties growth and development during the vegetation period in 2011 demonstrated long vegetation period of the most of the varieties tested. The density of plants was equal to 50 per $1 \mathrm{~m}^{2}$; height of plants reached $2.6 \mathrm{~m}$, the length of the stem to the upper internodes - up to $1.8 \mathrm{~m}$; green biomass amounted to $80 \mathrm{t} \cdot \mathrm{ha}^{-1}$.

The weather of 2013 was also typical to the northern Kazakhstan and in general was similar to the 2011. Winter of 2013 was characterized by sufficient snowfall, which contributed to moisture accumulation in the soil. A long period of snow melting, relatively cool weather in April, precipitations in April and May also contributed to the accumulation of moisture in the soil. The temperature in this period was slightly below the average rate $\left(-0.7^{\circ} \mathrm{C}\right)$. Sowing was also made in optimal time, May 31, in damp soil that yielded good amicable shoots. The amount of precipitation in June was of $11.6 \mathrm{~mm}$ or $28 \%$ of the average rate. However, a good soil pre-moisture, low insolation and air temperature, formation of secondary root system, allowed plants, especially the late-matured genotypes, to tolerate the June drought. July was characterized by 1.5 monthly norm of precipitation (165\%), which had a positive effect on the sorghum growth. At the same time, the temperature condition in July, as well as in May and June was below long-term mean at $0.7^{\circ} \mathrm{C}$. In August, $37.0 \mathrm{~mm}$ of rain fell, that is equal to long-term average rate. The total amount of precipitation was $169.6 \mathrm{~mm}$, which is very close to the long-term rate of $166.1 \mathrm{~mm}$.

The studied sorghum material depending on genotypes was characterized by a significant variation in the length of the vegetation period and durations of interphase periods: "sprouting-tasseling", "tasseling-ripening", that substantially determine the plants productivity. 

Northern Kazakhstan (for Feed and Biofuel)

Green biomass yields of sweet sorghum varieties studied were relatively high. At the near or similar weather conditions, the sorghum varieties demonstrated more or less stable productivity, which is important for sustainable production of this crop in northern Kazakhstan. The data of biomass yield of the varieties tested are presented in Table 2.

The results of the studies of 28 sweet sorghum genotypes demonstrated long-term vegetation period of the most samples of the tested material. By the time of early autumn frosts (mid-September), many of them were in the phase of booting. Only the varieties Krepysh, Saratovskoe 90 and Kinelskoye 4 reached maturity phase. These maturing at high latitude conditions genotypes can be suggested as promising for rainfed agriculture of northern Kazakhstan.

The pedigrees of these genotypes are listed below:

- Krepysh: $($ Var.894 $\times$ Dual $\times$ Saratovskoe 3C $\times$ AND-120C);

- Saratovskoe 90: (Saratovskoe 16C × Var.894E);

- Kinelskoye 4: (Kinelskoye $3 \times$ Saharnoe 20).

In the conditions of the northern Kazakhstan, the height of sweet sorghum plants ranged 90-245 cm. Green biomass yields varied from $19.78 \mathrm{t}^{-h^{-1}}$ to $108.89 \mathrm{t} \cdot \mathrm{ha}^{-1}$.

The high productivity of green mass was formed by the Russian genotypes Stavropolskoe 36, Larets and Chaika, the local varieties Kazakhstanskoe 20 and Kazakhstanskoe 16, and the variety Kulzha from China.

Table 2 Yields of sorghum genotypes.

\begin{tabular}{|c|c|c|c|c|}
\hline Genotype & $\begin{array}{l}\text { Phase of plants vegetation } \\
\text { (September } 3,2013 \text { ) }\end{array}$ & $\begin{array}{l}\text { Plants density } \\
\left(\mathrm{m}^{-2}\right)\end{array}$ & $\begin{array}{l}\text { Plants height } \\
(\mathrm{cm})\end{array}$ & Green biomass $\left(\mathrm{t} \cdot \mathrm{ha}^{-1}\right)$ \\
\hline Kazakhstanskoe 16 & Booting & 36.3 & 162 & 93.16 \\
\hline Kazakhstanskoe 20 & Booting & 33.3 & 151 & 106.67 \\
\hline Kazakhstanskoe 94 & Buttonhole & 40.0 & 204 & 81.33 \\
\hline Chaika & Bloom & 32.5 & 201 & 89.09 \\
\hline Flagman & Bloom & 35.5 & 245 & 82.96 \\
\hline Saratovskoe 90 & Milk ripeness & 38.5 & 202 & 52.64 \\
\hline Krepysh & Milk ripeness & 34.0 & 183 & 55.65 \\
\hline Kinelskoye 4 & Milk ripeness & 36.3 & 217 & 70.17 \\
\hline Stavropolskoe 36 & Buttonhole & 36.3 & 202 & 108.89 \\
\hline Galiya & Booting & 34.8 & 211 & 94.0 \\
\hline Larets & Booting & 37.0 & 183 & 104.94 \\
\hline Stavropolskoe 63 & Booting & 38.5 & 104 & 62.91 \\
\hline Silosnoe 88 & Bloom & 40.7 & 200 & 61.11 \\
\hline Alga & Buttonhole & 33.3 & 199 & 65.56 \\
\hline Oranzhevoe 160 & Booting & 22.9 & 140 & 67.36 \\
\hline Karabosh & Booting & 31.1 & 120 & 64.3 \\
\hline Uzbekistan 18 & Booting & 20.0 & 123 & 80.0 \\
\hline Vahshinskoe & Buttonhole & 52.5 & 148 & 82.4 \\
\hline ICSV 25274 & Booting & 15.5 & 128 & 54.96 \\
\hline ICSV 25275 & Booting & 13.3 & 119 & 30.22 \\
\hline ICSV 25280 & Booting & 6.6 & 123 & 19.78 \\
\hline ICSR 93034 & Booting & 17.0 & 107 & 65.31 \\
\hline ICSR 93039 & Booting & 15.5 & 90 & 45.11 \\
\hline ICSV 93046 & Booting & 17.7 & 140 & 58.67 \\
\hline SPV 1411 & Booting & 17.7 & 117 & 62.81 \\
\hline ICSSH 58 & Buttonhole & 31.8 & 220 & 97.68 \\
\hline ICSV 112 & Booting & 19.2 & 106 & 51.36 \\
\hline Kulzha & Booting & 30.3 & 186 & 104.27 \\
\hline
\end{tabular}



Northern Kazakhstan (for Feed and Biofuel)

Table 3 Assessment of the quality of the silage from green mass of sweet sorghum.

\begin{tabular}{|c|c|c|c|c|c|c|c|c|c|c|}
\hline \multirow[b]{2}{*}{ The silage option } & \multicolumn{5}{|c|}{15 days } & \multicolumn{5}{|c|}{30 days } \\
\hline & $\mathrm{pH}$ & $\begin{array}{l}\text { M. F. }{ }^{\text {a }} \text { of } \\
\text { acetic acid } \\
\text { in silage } \\
(\%)\end{array}$ & $\begin{array}{l}\text { M. F. of } \\
\text { butyric acid } \\
\text { in silage } \\
(\%)\end{array}$ & $\begin{array}{l}\text { M. F. }{ }^{a} \text { of } \\
\text { lactic acid } \\
\text { in silage } \\
(\%)\end{array}$ & $\begin{array}{l}\text { M. F. of } \\
\text { lactic acid } \\
\text { in the total } \\
\text { amount } \\
(\%)\end{array}$ & $\mathrm{pH}$ & $\begin{array}{l}\text { M. F. }{ }^{a} \text { of } \\
\text { acetic acid } \\
\text { in silage } \\
(\%)\end{array}$ & $\begin{array}{l}\text { M. F. }{ }^{\text {a }} \text { of } \\
\text { butyric acid } \\
\text { in silage } \\
(\%)\end{array}$ & $\begin{array}{l}\text { M. F. }{ }^{\text {a }} \text { of } \\
\text { lactic acid } \\
\text { in silage } \\
(\%)\end{array}$ & $\begin{array}{l}\text { M. F. }{ }^{\text {a }} \text { of } \\
\text { lactic acid } \\
\text { in the total } \\
\text { amount }{ }^{b} \\
(\%)\end{array}$ \\
\hline $\begin{array}{l}\text { Silage with no } \\
\text { additives (control) }\end{array}$ & 4.2 & 0.16 & 0.023 & 1.38 & 88.3 & 3.5 & 0.11 & 0.07 & 2.04 & 94.6 \\
\hline L. plantarum S-1 & 3.6 & 0.026 & 0.027 & 2.46 & 97.9 & 3.4 & 0.08 & 0.023 & 2.51 & 98.2 \\
\hline S. thermophilus F-1 & 3.6 & 0.026 & 0.011 & 2.41 & 94.7 & 3.4 & 0.074 & 0.025 & 2.51 & 96.2 \\
\hline L. bulgaricus F-2 & 3.9 & 0.19 & 0.025 & 2.01 & 91.3 & 3.6 & 0.268 & 0.022 & 2.21 & 97.7 \\
\hline S. cremoris S-3 & 4.0 & 0.15 & 0.0069 & 1.72 & 91.6 & 3.6 & 0.14 & 0.01 & 2.29 & 93.9 \\
\hline L. lactis F-4 & 3.7 & 0.032 & 0.019 & 2.21 & 93.6 & 3.5 & 0.028 & 0.033 & 2.22 & 97.3 \\
\hline L. acidophilus F-3 & 3.8 & 0.13 & 0.056 & 1.9 & 91.1 & 3.45 & 0.023 & 0.083 & 2.45 & 95.9 \\
\hline
\end{tabular}

${ }^{\mathrm{a}}$ Mass fraction; ${ }^{\mathrm{b}}$ in the total amount of lactic, acetic and butyric acids.

In the northern Kazakhstan conditions, the sweet sorghum can produce relatively high amount of soluble sugar, e.g., variety Oranzhevoe 160 contained $12.35 \%$, variety Uzbekistan $-11.95 \%$ of sugar. High sugar content is an important factor in the biomass processing, especially for biofuel and ensilage [9].

\subsection{Ensiling of Sweet Sorghum with Lactic Acid Bacteria}

A comparative assessment of the quality of sweet sorghum silages induced by the different strains of lactic acid bacteria was carried out. There were seven options/modifications of ensilage based on the studies of biochemical processes of fermentation and technological methods of processing of ensiling biomaterial.

The silage options with the strains Lactobacillus plantarum S-1, Streptococcus thermophilus F-1 and Lactococcus lactis F-4 (in accordance with GOST3638-90 [8]) can be considered as the first class of quality. The other options of silage, including the control one, can be considered as the third class of quality (Table 3).

\section{Conclusions}

For the first time in the high latitude rainfed conditions of northern Kazakhstan, the large-scale testings of sweet sorghum genotypes of the different ecological and geographic origin were carried out.

From the tested set of 28 sweet sorghum genotypes, three varieties (Krepysh, Kinelskoye 4 and Saratovskoe 90) reached to reproductive seeds stage. With average biomass yields of 55-70 tha $\mathrm{ha}^{-1}$, these genotypes can be selected for seed, feed and biofuel production in the northern Kazakhstan.

Some tested genotypes demonstrated high biomass production (100 tha $\mathrm{h}^{-1}$ and more) and can serve as donors of yield potential in breeding.

Lactic acid bacteria Lactobacillus plantarum S-1, Streptococcus thermophilus F-2 and Lactococcus lactis $F-4$ essentially enhance the fermentation process, suppressing undesirable microbiological processes, reducing the loss of nutrient compounds, accelerating the maturation ensilage process in 2 times, and providing higher quality of the feed product.

The research activities on sorghum introduction in the huge high-latitude Eurasian arid area are focused on two challenges for the region and country: (1) creation of sustainable feed base for the livestock; (2) ensuring biofuel production with alternative cheaper sources of raw materials. Wide introduction of the high productive drought resistant crops like sorghum, conservation agriculture, and effective processing technologies in the country as well as in Central Asia and Eurasia regions will enable to adaptation and mitigation to the global climate change. 

Northern Kazakhstan (for Feed and Biofuel)

\section{References}

[1] MoA (Ministry of Agriculture the Republic of Kazakhstan). 2012. Agro-business-2020: Program of the Agro-industrial Complex Development of the Republic of Kazakhstan. Astana, Kazakhstan: MoA.

[2] APAPK (Academy of the Public Administration under the President of Kazakhstan). 2012. Strategy "Kazakhstan-2050": New Political Course of the Established State. Astana, Kazakhstan: APAPK.

[3] APAPK (Academy of the Public Administration under the President of Kazakhstan). 2013. Decree of the President of the Republic of Kazakhstan "on Approval of the Concept of Kazakhstan on Transition to Green Economy”. Astana, Kazakhstan: APAPK.

[4] FAO (Food and Agriculture Organization of the United Nations). 2011. Save and Grow: A Policymaker's Guide to the Sustainable Intensification of Smallholder Crop
Production. Rome, Italy: FAO.

[5] FAO (Food and Agriculture Organization of the United Nations). 2010. Plant Genetic Resources for Food and Agriculture. The second report on the state of the world's plant genetic resources for food and agriculture.

[6] Zhuzhukin, V. I., and Semin, D. C. 2013. "Grain Sorghum in the Volga Region.” Agriculture 5: 29-30. (in Russian)

[7] McDonald, P., Henderson, A. R., and Heron, S. J. E. 1991. The Biochemistry of Silage. 2nd ed.. Kingston, Kent, UK: Chalcombe Publications.

[8] GOST (State Standard of the Russian Federation). 2002. Silage from Green Plants: GOST3638-98 Interstate Standard Specifications. Moscow, Russia: GOST .

[9] Vinutha, K. S., Laavanya R. K., Yadagiri, A. V., Umakanth, J. V., Patil, P., and Srinivasa, R. 2014. "Sweet Sorghum Research and Development in India: Status and Prospect." Sugar Tech. 16 (2): 133-43. 